\title{
Validitas dan Praktikalitas E-modul Sifat Koligatif Larutan Berbasis Guided Discovery Learning untuk Kelas XII SMA
}

\section{Validity and Practicality of Guided Discovery Based E-module on Colligative Properties of Solutions for XII Grade Senior High School Students}

\author{
M Sari ${ }^{1}$ and Yerimadesi ${ }^{1^{*}}$ \\ 1 Pendidikan Kimia, Universitas Negeri Padang, \\ Jl. Prof. Dr. Hamka, Air Tawar Barat, Padang Utara, Sumatera Barat, Indonesia 25171 \\ *yeri@fmipa.unp.ac.id
}

\section{ARTICLE INFO \\ Received on: \\ 27 January 2021 \\ Revised till: \\ 15 July 2021}

Accepted on:

25 July 2021

Publisher version published on:

08 September 2021

\begin{abstract}
Guided discovery learning based E-module is a teaching material in electronic to support independent learning that follow the stages of guided discovery learning model. The development research was conducted to develop and analyse the validity and practicality of this e-module on colligative properties of solution material for class XII high school chemistry learning. The type of research is educational design research using the Plomp development model consisting of (1) preliminary research, (2) prototyping stage, (3) assessment phase. The e-module was validated by eight validators who are four UNP chemistry lecturers and four chemistry teachers using an instrument in the form of validity questionnaire, while the practicality test was carried out at SMA N 8 Padang by 27 students and three teachers with an instrument in the form of a practicality questionnaire. The questionnaire analysis was performed using the Content Validity Ratio (CVR) for content validation and Aiken's $V$ formula for construct validation and practicality. From the results, the data indicate that the solution based colligative properties e-module based on guided discovery learning for chemistry learning in class XII senior high school has valid and practical values.
\end{abstract}

\section{KEYWORDS}

Colligative Properties, E-module, Guided Discovery Learning, Practicality, Validity

\begin{abstract}
ABSTRAK
E-modul berbasis guided discovery learning merupakan bahan ajar dalam bentuk elektronik untuk mendukung pembelajaran mandiri yang dilengkapi dengan tahapan guided discovery learning. Penelitian pengembangan bertujuan mengembangkan dan menganalisis validitas dan praktikalitas e-modul sifat koligatif larutan berbasis guided discovery learning untuk pembelajaran kimia SMA kelas XII. Jenis penelitian yang dilakukan berupa educational design research dengan menggunakan model pengembangan Plomp yang terdiri atas (1) preliminary research, (2) prototyping stage, (3) assessment phase. E-modul divalidasi oleh delapan validator yang terdiri dari empat dosen kimia UNP dan empat guru kimia dengan menggunakan instrumen berupa angket validitas, sedangkan uji praktikalitas dilaksanakan di SMA N 8 Padang oleh 27 peserta didik dan tiga orang guru dengan instrumen berupa angket praktikalitas. Teknik analisis data dilakukan dengan menggunakan Content Validity Ratio (CVR) untuk validasi konten dan formula Aiken's V untuk validasi konstruk dan praktikalitas. Dari hasil analisis data dapat disimpulkan bahwa e-modul sifat koligatif larutan berbasis guided discovery learning untuk pembelajaran kimia SMA kelas XII mempunyai nilai valid dan praktis.
\end{abstract}

\section{KATA KUNCI}

E-modul, Guided Discovery Learning, Praktikalitas, Sifat Koligatif Larutan, Validitas 


\section{PENDAHULUAN}

Berdasarkan kurikulum 2013 sifat koligatif larutan merupakan materi kimia SMA yang memiliki dimensi pengetahuan faktual, konseptual, prosedural dan metakognitif, serta memiliki ranah konkret dan abstrak. Oleh karena itu, peserta didik dituntut agar dapat ikut terlibat aktif dalam memecahkan masalah dan guru sebagai motivator yang dapat memotivasi peserta didik agar dapat meningkatkan potensi dirinya ${ }^{[1]}$. Materi sifat koligatif larutan mempunyai tiga aspek yaitu makroskopik, submikroskopik, dan simbolik sehingga diperlukan pemahaman mendalam terkait materi tersebut.

Hasil pengisian angket pada tiga SMA di kota Padang menyatakan bahwasanya guru menggunakan buku cetak, Lembar Kerja Peserta Didik (LKPD), dan modul sebagai bahan ajar. Hasil angket selanjutnya menyatakan $78,5 \%$ peserta didik mengalami kesulitan untuk memahami konsep sifat koligatif larutan, ini diakibatkan oleh pembelajaran yang berpusat pada guru dan rendahnya motivasi peserta didik. Pernyataan ini didukung oleh pendapat ${ }^{[2]}$ bahwa kurangnya partisipasi peserta didik dalam proses pembelajaran mengakibatkan peserta didik kesulitan untuk menemukan konsep dan menyelesaikan soal yang memerlukan pemahaman konsep.

Salah satu model pembelajaran yang dapat memotivasi peserta didik agar dapat terlibat aktif dalam kegiatan pembelajaran adalah guided discovery learning. Guru membimbing kegiatan pembelajaran melalui pertanyaan yang dapat mengarahkan peserta didik untuk menemukan konsep ${ }^{[3]}$. Pelaksanaan model guided discovery learning dalam proses pembelajaran menurut pendapat Khasanah, Usodo dan Subanti ${ }^{[4]}$ mampu meningkatkan kemampuan untuk mengingat materi yang sedang dipelajari, meningkatkan hasil belajar dan menurut pendapat Sulistyowati, Widodo dan Sumarni ${ }^{[5]}$ efektif terhadap kemampuan pemecahan masalah. Bahan ajar yang banyak digunakan pada penerapan guided discovery learning berupa modul. pengembangan modul berbasis guided discovery learning yang dikembangkan pada materi redoks dan sel elektrokimia oleh Yerimadesi diperoleh hasil bahwasanya modul tersebut valid dan praktis ${ }^{[6]}$.

Pemahaman materi sifat koligatif larutan yang bersifat abstrak dapat lebih mudah dipahami dengan adanya pemodelan atau animasi melalui video agar meminimalisir kesalahan konsep ${ }^{[7]}$. Sedangkan modul hanya memuat gambar dua dimensi dan tidak dilengkapi dengan audio dan video $^{[8]}$. Oleh karena itu dilakukan inovasi bahan ajar dengan memanfaatkan penggunaan Teknologi, Informasi, dan Komunikasi (TIK) yang sesuai dengan prinsip pembelajaran kurikulum 2013 ${ }^{[9]}$, salah satunya berupa elektronik modul (e-modul).

E-modul dapat dijadikan alternatif bahan ajar pada masa pembatasan sosial berskala besar yang mengganggu keterlaksanaan proses pembelajaran secara konvensional. Berdasarkan penelitian sebelumnya penggunaan e-modul bisa membuat peserta didik belajar mandiri ${ }^{[10]}$, meningkatkan pemahaman matematis ${ }^{[11]}$ meningkatkan kemampuan kompetensi pengetahuan peserta $\operatorname{didik}^{[12]}$, serta meningkatkan hasil belajar dan keterampilan berpikir kritis ${ }^{[13]}$. Dari permasalahan tersebut dilakukan pengembangan e-modul sampai tahapan uji validitas dan praktikalitas sebagai bahan ajar yang dapat dijadikan alternatif pendukung dalam pelaksanaan proses pembelajaran.

\section{METODE}

Desain penelitian ini adalah educational design research yang dikemukakan oleh Plomp. Penelitian pengembangan ini selain digunakan untuk menghasilkan produk dan memperoleh tingkat kepraktisan dan keefektifan produk, serta dapat dilakukan untuk menyempurnakan produk yang telah dikembangkan sebelumnya ${ }^{[14]}$. Penelitian ini menghasilkan e-modul yang berjudul sifat koligatif larutan berbasis guided discovery learning untuk pembelajaran kimia SMA kelas XII. E-modul dirancang menggunakan model Plomp dengan tiga tahapan pengembangan, yaitu (1) tahap penelitian pendahuluan (preliminary research), (2) tahap pembentukan prototipe (prototyping stage) yang terdiri atas tiga prototipe, dan (3) tahap penilaian (assessment phase) ${ }^{[15]}$.

Dalam preliminary research digunakan untuk analisis mendalam terkait materi dengan melakukan analisis kebutuhan, konteks, studi literatur, serta pembentukan kerangka konseptual. Analisis kebutuhan dilakukan untuk melihat kondisi di lapangan terkait dengan kendala yang dialami saat kegiatan pembelajaran berlangsung. Kegiatan difokuskan pada masalah yang terjadi, terutama berkaitan dengan bahan ajar yang digunakan. Analisis konteks dilakukan dengan menganalisis Kompetensi Dasar (KD) untuk diturunkan menjadi Indikator Pencapaian Kompetensi (IPK) dan tujuan pembelajaran. Selanjutnya dilakukan studi literatur terkait referensi yang mendukung penelitian dan pengembangan kerangka konseptual.

Tahap pembentukan prototipe (prototyping stage) dilakukan dengan merancang e-modul berdasarkan hasil preliminary research untuk dilakukan evaluasi formatif di setiap prototipe. Tahapan selanjutnya dilakukan uji coba lapangan (assessment phase) terhadap e-modul yang dihasilkan untuk mengetahui tingkat praktikalitas dari e-modul. Instrumen yang digunakan berupa angket validasi konten, konstruk dan praktikalitas. Uji validasi konten dan konstruk melibatkan empat dosen kimia dan empat guru kimia, sedangkan untuk uji praktikalitas melibatkan tiga guru kimia dan 27 peserta didik SMA.

Untuk data lembar angket validitas konten dihitung dengan Content Validity Ratio (CVR) ${ }^{[16]}$ yang dapat dilihat pada Persamaan 1, dimana ne adalah jumlah validator yang menjawab penting; serta $N$ merupakan jumlah total validator. 


$$
\mathrm{CVR}=\frac{n e-N / 2}{N / 2} \ldots \text { Persamaan } 1
$$

Suatu item diterima jika perolehan nilai lebih besar ataupun sama dengan nilai kritis CVR sesuai dengan jumlah validator, serta ditolak jika perolehan nilai lebih kecil dari nilai kritis ${ }^{[17]}$. Nilai kritis CVR dapat dilihat pada Tabel 1.

Tabel 1. Nilai Kritis CVR ${ }^{[16]}$.

\begin{tabular}{c|c} 
Jumlah Validator & Nilai Kritis CVR \\
\hline 5 & 0,736 \\
\hline 6 & 0,672 \\
\hline 7 & 0,622 \\
\hline 8 & 0,582
\end{tabular}

Analisis untuk data validitas konstruk dan praktikalitas menggunakan persamaan Aiken's V ${ }^{[18]}$. Formula Aiken's V dapat dilihat pada Persamaan 2 dan Persamaan 3. Dimana, $V$ adalah nilai Aiken's V; lo adalah skor terendah dalam kategori; $c$ adalah banyak kategori yang dapat dipilih; $r$ adalah skor yang diberikan penilai; serta $n$ adalah banyaknya penilai. Selanjutnya, kriteria validitas dan praktikalitas dapat dilihat pada Tabel 2.

$$
\begin{gathered}
V=\frac{\sum s}{n(c-1)} \ldots \text { Persamaan } 2 \\
S=r-l o \ldots \text { Persamaan } 3
\end{gathered}
$$

Tabel 2. Kriteria Skala Aiken's V ${ }^{[19]}$.

\begin{tabular}{c|c} 
Skala Aiken's V & Kategori \\
\hline $\mathrm{V}<0,4$ & Rendah \\
\hline $0,4<\mathrm{V} \leqslant 0,8$ & Sedang \\
\hline $0,8<\mathrm{V}$ & Tinggi
\end{tabular}

\section{HASIL DAN DISKUSI}

\subsection{Tahap Penelitian Pendahuluan (Preliminary Research)}

\subsubsection{Analisis Kebutuhan}

Dari hasil analisis angket guru dan peserta didik diperoleh (1) 78,5\% peserta didik kurang memahami materi sifat koligatif larutan; (2) proses pembelajaran masih berpusat pada peserta didik, dimana guru memiliki hambatan berupa media pembelajaran yang tersedia tidak mendukung; (3) bahan ajar yang terdapat di sekolah berupa buku cetak, LKPD, dan modul. Oleh karena itu sesuai dengan pembelajaran abad 21 dan revolusi 4.0, serta untuk mendukung peserta didik belajar secara mandiri perlu adanya e-modul berbasis guided discovery learning untuk membantu pemahaman peserta didik dan penerapan student center learning ${ }^{[20]}$.

\subsubsection{Analisis Konteks}

Pada tahap ini, dilakukan analisis kurikulum dan silabus sehingga diperoleh Kompetensi Dasar (KD) pada materi sifat koligatif larutan yang akan diturunkan menjadi Indikator Pencapaian

\begin{tabular}{|c|c|}
\hline $\begin{array}{l}\text { Kompetensi Dasar } \\
\text { (KD) }\end{array}$ & $\begin{array}{c}\text { Indikator Pencapaian } \\
\text { Kompetensi (IPK) }\end{array}$ \\
\hline \multirow{5}{*}{$\begin{array}{l}3.1 \text { Menganalisis } \\
\text { fenomena sifat } \\
\text { koligatif larutan } \\
\text { (penurunan tekanan } \\
\text { uap, kenaikan titik } \\
\text { didih, penurunan } \\
\text { titik beku, tekanan } \\
\text { osmosis. }\end{array}$} & $\begin{array}{l}\text { 3.1.1 Menganalisis } \\
\text { pengaruh zat terlarut } \\
\text { terhadap penurunan } \\
\text { tekanan uap suatu } \\
\text { larutan }\end{array}$ \\
\hline & $\begin{array}{l}\text { 3.1.2 Menganalisis } \\
\text { pengaruh zat terlarut } \\
\text { terhadap kenaikan titik } \\
\text { didih suatu larutan }\end{array}$ \\
\hline & $\begin{array}{l}\text { 3.1.3 Menganalisis } \\
\text { pengaruh zat terlarut } \\
\text { terhadap penurunan titik } \\
\text { beku suatu larutan }\end{array}$ \\
\hline & $\begin{array}{l}\text { 3.1.4 Menganalisis } \\
\text { diagram P-T untuk } \\
\text { menafsirkan penurunan } \\
\text { tekanan uap, kenaikan } \\
\text { titik didih, dan } \\
\text { penurunan titik beku } \\
\text { larutan }\end{array}$ \\
\hline & $\begin{array}{l}\text { 3.1.5 Menganalisis } \\
\text { peristiwa osmosis suatu } \\
\text { larutan dalam kehidupan } \\
\text { sehari-hari }\end{array}$ \\
\hline $\begin{array}{l}\text { 3.2 Membedakan } \\
\text { sifat koligatif larutan } \\
\text { elektrolit dan non- } \\
\text { elektrolit }\end{array}$ & $\begin{array}{l}\text { 3.2.1 Membandingkan } \\
\text { sifat koligatif larutan } \\
\text { elektrolit dan } \\
\text { nonelektrolit }\end{array}$ \\
\hline $\begin{array}{l}\text { 4.1 Menyajikan } \\
\text { hasil penelusuran } \\
\text { informasi tentang } \\
\text { kegunaan prinsip } \\
\text { sifat koligatif larutan } \\
\text { dalam kehidupan } \\
\text { sehari-hari }\end{array}$ & $\begin{array}{l}\text { 4.1.1 Memaparkan } \\
\text { kegunaan prinsip sifat } \\
\text { koligatif larutan dalam } \\
\text { kehidupan sehari-hari }\end{array}$ \\
\hline $\begin{array}{l}\text { 4.2 Menganalisis data } \\
\text { percobaan untuk } \\
\text { menentukan derajat } \\
\text { pengionan }\end{array}$ & $\begin{array}{l}\text { 4.2.1 Menganalisis data } \\
\text { hasil percobaan sifat } \\
\text { koligatif larutan untuk } \\
\text { menentukan derajat } \\
\text { pengionan. }\end{array}$ \\
\hline
\end{tabular}
Kompetensi (IPK) yang bisa dilihat pada Tabel 3.

Tabel 3. KD dan IPK Materi Sifat Koligatif Larutan.

Tujuan pembelajaran yang dapat dirumuskan berdasarkan indikator pada Tabel 3 adalah "Melalui e-modul berbasis guided discovery learning dengan menggali informasi dari berbagai sumber belajar, penyelidikan sederhana dan mengolah informasi dari berbagai sumber, diharapkan peserta didik terlibat 
aktif selama proses belajar mengajar berlangsung, memiliki sikap ingin tahu, teliti dalam melakukan pengamatan dan bertanggung jawab dalam menyampaikan pendapat, menjawab pertanyaan, memberi saran, dan kritik, serta dapat menganalisis fenomena sifat koligatif larutan (penurunan tekanan uap, kenaikan titik didih, penurunan titik beku dan tekanan osmosis), membedakan sifat koligatif larutan elektrolit dan nonelektrolit, menyajikan hasil penelusuran informasi tentang kegunaan prinsip sifat koligatif larutan dalam kehidupan sehari-hari, dan menganalisis data percobaan untuk menentukan derajat pengionan dengan tepat”.

\subsubsection{Studi Literatur}

Hasil studi literatur diperoleh bahwa komponen e-modul merujuk pada panduan praktis penyusunan e-modul yaitu cover, daftar isi, pendahuluan, kegiatan pembelajaran, latihan, penilaian diri, evaluasi, kunci jawaban, pedoman penskoran, dan daftar pustaka ${ }^{[9]}$. Untuk isi materi sifat koligatif larutan dalam e-modul merujuk pada text book. Sintaks guided discovery learning merujuk pada buku model guided discovery learning untuk pembelajaran kimia (GDL-PK) dengan langkah yaitu motivation and problem, data collection, data processing, verification, dan closure ${ }^{[21]}$, untuk model pengembangan Plomp merujuk pada buku An introduction to educational design research dengan langkah (1) penelitian pendahuluan (preliminary research), (2) prototyping stage) dan tahap penilaian (assessment phase) ${ }^{[15]}$.

\subsubsection{Pengembangan Kerangka Konseptual}

Berdasarkan hasil analisis kebutuhan dan konteks didapatkan bahwa diperlukan suatu bahan ajar yang dapat membantu peserta didik dalam memahami konsep sifat koligatif larutan secara mandiri dan sesuai dengan tuntutan pembelajaran abad 21. Konsep-konsep yang terdapat dalam bahan ajar tersebut harus sesuai dengan analisis silabus dan kurikulum 2013. Sehingga dikembangkan e-modul sifat koligatif larutan yang didalamnya terdapat tahapan model guided discovery learning yang disusun berdasarkan panduan praktis penyusunan e-modul dan dikembangkan dengan model pengembangan Plomp.

\subsection{Tahap Pembentukan Prototipe (Prototyping Stage)}

\subsubsection{Prototipe I}

Pada tahap ini dilakukan desain e-modul dengan hasil prototipe I dalam bentuk e-modul sifat koligatif larutan berbasis guided discovery learning untuk pembelajaran kimia SMA kelas XII dengan komponen seperti yang disebutkan pada studi literatur dan disusun dengan sintaks guided discovery learning.

\subsubsection{Prototipe II}

Hasil prototipe I dilakukan self evaluation berupa daftar checklist terkait komponen yang harus ada dalam e-modul. Berdasarkan hasil yang diperoleh dibutuhkan revisi terhadap komponen e-modul yang belum lengkap dan hasil revisi berupa prototipe II.

\subsubsection{Prototipe III}

\subsubsection{One to One Evaluation}

Pada tahap ini dilaksanakan uji coba e-modul dari hasil prototipe II yang telah direvisi kepada tiga orang peserta didik SMA yang memiliki tingkatan kemampuan yang berbeda (tinggi, sedang dan rendah). Dari evaluasi ini diperoleh bahwa pemilihan warna pada cover dan isi e-modul dapat memberikan daya tarik kepada peserta didik, huruf yang digunakan jelas sehingga mudah terbaca dan penggunaan bahasa yang sesuai dengan Ejaan Bahasa Indonesia (EBI).

\subsubsection{Expert Review (Penilaian Ahli)}

Pada tahap ini dilakukan uji validasi terhadap e-modul oleh empat dosen kimia UNP dan empat guru kimia berupa validasi konten dan validasi konstruk. Validasi konten terdiri atas dua aspek penilaian yaitu aspek kesesuaian isi e-modul dengan sintaks guided discovery learning dan aspek kesesuaian isi e-modul dengan keilmuan kimia. Aspek penilaian konstruk terdiri atas empat komponen yaitu isi, kebahasaan, penyajian dan kegrafikan ${ }^{[22]}$.

\subsection{Validasi Konten}

Penentuan keputusan kevalidan berdasarkan pada nilai kritis CVR dimana pada penelitian ini dilakukan oleh delapan validator sehingga nilai kritis CVR sebesar 0,582. Hasil validasi konten e-modul bisa dilihat pada Tabel 4 .

Tabel 4. Hasil Validasi Konten E-modul.

\begin{tabular}{c|c|c} 
Aspek & $\begin{array}{c}\text { Nilai } \\
\text { CVR }\end{array}$ & Kategori \\
\hline $\begin{array}{c}\text { Kesesuaian isi } \\
\text { e-modul dengan sintaks } \\
\text { guided discovery learning }\end{array}$ & 0,99 & Valid \\
\hline $\begin{array}{c}\text { Kesesuaian isi } \\
\text { e-modul dengan } \\
\text { konten keilmuan kimia }\end{array}$ & 0,90 & Valid \\
\hline Rata-rata & $\mathbf{0 , 9 4 5}$ & Valid
\end{tabular}

Aspek kesesuaian isi dengan sintaks guided discovery learning memiliki nilai CVR 0,99 (valid), ini menunjukkan bahwa e-modul yang dihasilkan sesuai dengan lima sintaks guided discovery learning yang akan memotivasi dan membimbing peserta didik dalam menemukan konsep ${ }^{[23]}$. Penilaian aspek kebenaran isi e-modul dengan keilmuan kimia diperoleh nilai CVR 0,90 (valid), ini menunjukkan bahwa aspek diterima oleh validator karena perolehan nilai lebih besar dari 0,582. Secara keseluruhan validasi konten memiliki rata-rata nilai CVR 0,945 (valid), kategori ini akan semakin tinggi jika nilai CVR mendekati satu ${ }^{[24]}$. 


\subsection{Validasi Konstruk}

Validasi konstruk untuk keseluruhan konsep yang dihasilkan pada penelitian ini bisa dilihat pada Tabel 5 .

Tabel 5. Hasil Analisis Validasi Konstruk.

\begin{tabular}{c|c|c} 
Komponen & $\begin{array}{c}\text { Nilai } \\
\text { Aiken's V }\end{array}$ & $\begin{array}{c}\text { Kategori } \\
\text { Kevalidan }\end{array}$ \\
\hline Isi & 0,85 & Tinggi \\
\hline Kebahasaan & 0,86 & Tinggi \\
\hline Penyajian & 0,90 & Tinggi \\
\hline Kegrafikan & 0,86 & Tinggi \\
\hline Rata-rata & $\mathbf{0 , 8 7}$ & Tinggi
\end{tabular}

Aspek komponen isi e-modul sifat koligatif larutan mempunyai nilai rata-rata Aiken's V 0,85 (validitas tinggi), ini menunjukkan bahwa e-modul sesuai dengan prinsip pengembangan bahan ajar yaitu mencakup kesesuaian materi dengan tuntutan Kompetensi Dasar (KD $)^{[25]}$. Aspek kelayakan isi e-modul meliputi kesesuaian materi dengan KI, KD, IPK, tujuan pembelajaran dan ketersesuaian materi dengan kemampuan peserta didik ${ }^{[26]}$.

Aspek komponen kebahasaan e-modul mempunyai rata-rata nilai Aiken's $\mathrm{V}$ sebesar 0,86 (kevalidan tinggi), Hal ini memperlihatkan bahwa e-modul yang dihasilkan sudah sesuai dengan Ejaan Bahasa Indonesia yang baik, sederhana dan jelas sehingga mudah dipahami pengguna. E-modul yang baik memiliki bahasa yang komunikatif, menggunakan istilah umum sehingga bersifat user friendly ${ }^{[27]}$.

Aspek komponen penyajian pada e-modul memiliki rata-rata nilai Aiken's V 0,90 (kevalidan tinggi), ini menunjukkan bahwa penyajian pada e-modul yang telah disusun secara sistematis sesuai panduan penyusunan e-modul. Selain itu, e-modul telah sesuai dengan sintaks guided discovery learning.

Aspek komponen kegrafikan dari e-modul memiliki rata-rata nilai Aiken's V 0,86 (kevalidan tinggi). Aspek ini terkait dengan tampilan dan desain dari e-modul (layout, gambar, symbol dan animasi) yang disajikan dengan proporsi yang sesuai dan menarik sehingga dapat mendorong minat peserta didik untuk belajar ${ }^{[28]}$.

Secara keseluruhan nilai rata-rata Aiken's V untuk seluruh komponen sebesar 0,87 (kevalidan tinggi), ini memperlihatkan bahwa e-modul yang dikembangkan valid. Namun, diperlukan perbaikan di berbagai bagian yang dianggap validator kurang.

\subsubsection{Prototipe $I V$}

Prototipe IV dilaksanakan dengan small group evaluation kepada enam peserta didik. Hasil evaluasi ini akan menghasilkan tingkat praktikalitas pada skala kecil. Keseluruhan dari ketiga aspek diperoleh rata-rata nilai Aiken's V sebesar 0,83 (kepraktisan tinggi). Sehingga e-modul tersebut sudah bisa diuji cobakan pada tahap field test dengan melakukan revisi di bagian tertentu.

\subsection{Tahap Penilaian (Assessment Phase)}

Tahapan ini dilakukan dengan uji lapangan (field test). Hasil dari field test didapatkan nilai kepraktisan e-modul oleh guru dan peserta didik yang bisa dilihat pada Tabel 6 .

Tabel 6. Hasil Analisis Praktikalitas Respon Peserta Didik dan Guru.

\begin{tabular}{c|c|c|c|c} 
& \multicolumn{4}{|c}{ Nilai Aiken's V } \\
dan Kategori Kepraktisan \\
$\begin{array}{c}\text { Kompo- } \\
\text { nen }\end{array}$ & $\begin{array}{c}\text { Peserta } \\
\text { Didik }\end{array}$ & $\begin{array}{c}\text { Kep- } \\
\text { rakti- } \\
\text { san }\end{array}$ & Guru & $\begin{array}{c}\text { Kep- } \\
\text { rakti- } \\
\text { san }\end{array}$ \\
\cline { 2 - 5 } & & Tinggi & 0,81 & Tinggi \\
\hline $\begin{array}{c}\text { Kemu- } \\
\text { dahan } \\
\text { penggu- } \\
\text { naan }\end{array}$ & 0,82 & Sedang & 0,83 & Tinggi \\
\hline $\begin{array}{c}\text { Efisiensi } \\
\text { waktu } \\
\text { pembel- } \\
\text { ajaran }\end{array}$ & 0,80 & Tinggi & 0,82 & Tinggi \\
\hline Manfaat & 0,81 & Tinggi & $\mathbf{0 , 8 2}$ & Tinggi \\
\hline $\begin{array}{c}\text { Rata- } \\
\text { rata }\end{array}$ & $\mathbf{0 , 8 1}$ & &
\end{tabular}

Dari segi komponen kemudahan penggunaan e-modul berdasarkan angket peserta didik didapatkan nilai sebesar 0,82 (kepraktisan tinggi) dan berdasarkan respon guru sebesar 0,81 (kepraktisan tinggi). Data ini memperlihatkan bahwa e-modul mudah digunakan, pertanyaanpertanyaan yang terdapat di dalam e-modul jelas, penggunaan bahasa mudah dipahami. Huruf yang terdapat dalam e-modul mudah dibaca dan e-modul memiliki ukuran yang praktis sehingga dapat digunakan secara berulang kali.

Dari segi komponen efisiensi waktu pembelajaran didapatkan nilai Aiken's V sebesar 0,83 (kepraktisan tinggi), sedangkan nilai Aiken's dari respon peserta didik sebesar 0,80 (kepraktisan sedang). Hal ini memperlihatkan bahwasanya e-modul yang dihasilkan sudah sesuai dengan tujuan dari bahan ajar yaitu untuk mempermudah guru dan menjadikan waktu pembelajaran lebih efisien.

Hasil validasi komponen manfaat e-modul berdasarkan penilaian dari guru dan peserta didik melalui angket didapatkan nilai Aiken's V masing-masing sebesar 0,82 (kepraktisan tinggi) dan 0,81 (kepraktisan tinggi). Hal tersebut memperlihatkan bahwasanya e-modul yang dihasilkan dapat membantu peserta didik agar dapat belajar secara mandiri dalam memahami konsep melalui video, animasi, gambar dan pertanyaan yang terdapat pada e-modul.

Secara keseluruhan nilai rata-rata Aiken's V untuk e-modul dari respon peserta didik dan guru adalah 0,81 dan 0,82 dengan kepraktisan tinggi. Setelah dilakukan field test terhadap prototipe IV, 
dilakukan penyempurnaan pada bagian tertentu dan dihasilkan prototipe final berupa e-modul sifat koligatif larutan berbasis guided discovery learning untuk pembelajaran kimia SMA kelas XII yang valid dan praktis.

\section{SIMPULAN}

Kesimpulan dari penelitian ini adalah e-modul sifat koligatif larutan berbasis guided discovery learning untuk pembelajaran kimia SMA kelas XII dengan model pengembangan Plomp mempunyai kategori validitas konten dan konstruk yang valid serta mempunyai nilai praktikalitas yang tinggi.

\section{REFERENSI}

1. Majid A, Rochman C. Pendekatan Ilmiah dalam Implementasi Kurikulum 2013. Bandung: Remaja Rosdakarya; 2014.

2. Mairisiska T, Sutrisno, Asrial. Pengembangan Perangkat Pembelajaran Berbasis TPACK pada Materi Sifat Koligatif Larutan untuk Meningkatkan Keterampilan Berpikir Kritis Siswa Development TPACK Based Learning Devices on Colligative Properties to Improve Critical Thinking Skill Students. Edu-Sains. 2014;3:28-37.

3. Martin AJ. Teaching Academically At-Risk Students in Middle School: The Roles of Explicit Instruction and Guided Discovery Learning Middle. 2015;207-23.

4. Khasanah VN, Usodo B, Subanti S. Guided Discovery Learning in Geometry Learning. J Phys Conf Ser. 2018;983(1).

5. Sulistyowati N, Widodo AT, Sumarni W. Efektivitas Model Pembelajaran Guided Discovery Learning Terhadap Kemampuan Pemecahan Masalah Kimia. Chem Educ. 2012;1(2).

6. Bayharti B, Azumar OR, Andromeda A, Yerimadesi Y. Effectiveness of Redox and Electrochemical Cell Module Based Guided Discovery Learning on Critical Thinking Skills and Student Learning Outcomes of High School. J Phys Conf Ser. 2019;1317(1).

7. Anugerah S, Effendy E, Suharti S. Analisis Kesalahan Konsep Sifat Koligatif Larutan Pada Mahasiswa Kimia Universitas Negeri Malang Dan Eliminasinya Menggunakan Media Visualisasi Statik. J Ilmu Pendidik Univ Negeri Malang. 2017;21(2):114818.

8. Priyanthi KA, Agustini K, Santyadiputra GS. Pengembangan E-Modul Berbantuan Simulasi Berorientasi Pemecahan Masalah Pada Mata Pelajaran Komunikasi Data (Studi Kasus: Siswa Kelas XI TKJ SMK Negeri 3 Singaraja). Kumpul Artik Mhs Pendidik Tek Inform. 2017;6(1):40.

9. Kemdikbud. Panduan Praktis Penyusunan E-Modul. In Jakarta: Direktorat Pembinaan Sekolah Menengah Atas; Direktorat Jenderal Pendidikan Dasar dan Menengah; Kementerian Pendidikan dan Kebudayaan. 2017;1-57.
10. Susilawati S, Pramusinta P, Saptaningrum E. Penguasaan Konsep Siswa Melalui Sumber Belajar e-Modul Gerak Lurus dengan Software. Unnes Phys Educ J. 2020;9(1):36-43.

11. Aldeliana E. Pengembangan E-modul Berbasis Challenging Task untuk Meningkatkan Kemampuan Pemahaman Konsep Matematis Peserta Didik Kelas X di SMA Negeri 1 Tempilang. Universita. Lampung; 2019.

12. Solihudin JH T. Pengembangan E-Modul Berbasis Web untuk Meningkatkan Pencapaian Kompetensi Pengetahuan Fisika Pada Materi Listrik Statis dan Dinamis SMA. WaPFi (Wahana Pendidik Fis. 2018;3(2):51.

13. Sujanem R, Suwindra INP, Suswandi I. Efektivitas E-Modul Fisinberma dalam Ujicoba Terbatas untuk Meningkatkan Keterampilan Berpikir Kritis Siswa SMAN 2 Singaraja. Semin Nas Ris Inov. 2018;(2):260-6.

14. Haryati S. Research and Development (R\&D) Sebagai Salah Satu Model Penelitian dalam Bidang Pendidikan. Res Dev Sebagai Salah Satu Model Penelit dalam Bid Pendidik. 2012;37(1):11-26.

15. Plomp T, Nieveen N. An Introduction to Educational Design Research. In: Proceedings of the seminar conducted at the east China Normal University, Shanghai (PR China) November 23-26,2007. Netherlands Institute for Curriculum Development: SLO; 2007.

16. Wilson FR, Pan W, Schumsky DA. Recalculation of the Critical Values for Lawshe's content Validity Ratio. J Meas Eval Conseling Dev. 2012;45(3):197-210.

17. Allahyari T, Rangi NH, Khosravi Y, Zayeri F. Development and Evaluation of a New Questionnaire for Rating of Cognitive Failures at Work. Int J Occup Hyg. 2011;3(1):6-11.

18. Aiken LR. Content Validity and Realiabiity of Single Items or Questionnaires. Educ Psychol Meas. 1980;(40):955-9.

19. Retnawati H. Analisis Kuantitatif Instrumen Penelitian. Yogyakarta: Parama Publishing; 2016. 210 p.

20. Udo ME. Effect of Guided-Discovery, StudentCentred Demonstration and the Expository Instructional Strategies on Students' Performance in Chemistry ( Pp . 389-398 ). Index African Journals. 2010;4(16):389-98.

21. Yerimadesi, Kiram Y, Lufri, Festiyed. Buku Model Guided Discovery Learning untuk Pembelajaran Kimia (GDL-PK) SMA. Pandang: Pasca Sarjana Universitas Negeri Padang; 2017.

22. Depdiknas. Panduan Pengembangan Bahan Ajar. Jakarta: Direktorat Pembina Sekolah Menengah Atas; 2008.

23. Smitha. Inquiry Training Model and Guided Discovery Learning For Fostering Critical Thinking and Scientific Attitude. Kozhikode: Vilavath Publication; 2012.

24. Hendryadi. Content validity (Validitas Isi). Teor Pers Pap. 2014;01(01):1-5. 
25. Desyandri, Muhammadi, Mansurdin, Fahmi R. Development of Integrated Thematic Teaching Material Used Discovery Learning Model in Grade V Elementary School. J Konseling dan Pendidik. 2019;7(1):16.

26. Purwanto N. Prinsip-prinsip dan Teknik Evaluasi Pengajaran. Bandung: Remaja Rosdakarya; 2012.

27. Aisyi FK, Elvyanti S, Gunawan T, Mulyana E. Pengembangan Bahan Ajar Tik Smp Mengacu Pada Pembelajaran Berbasis Proyek. Innov Vocat Technol Educ. 2017;9(2):117-28.

28. Hamdani. Strategi Belajar Mengajar. Bandung: Pustaka Setia; 2011.

\section{UCAPAN TERIMA KASIH}

Ucapan terima kasih penulis sampaikan kepada Lembaga Penelitian dan Pengabdian Masyarakat (LP2M) Universitas Negeri Padang yang telah mendanai penelitian ini melalui dana DIPA UNP Nomor SP DIPA-023.17.2.677514/2021, Tanggal 23 November 2020. 